\title{
ANALISIS EFEKTIVITAS POMPA DISTRIBUSI PDAM IPA II BANDARMASIH DENGAN MENGGUNAKAN METODE OVERALL EQUIPMENT EFFECTIVENESS
}

\author{
Cinthia Amalia ${ }^{1}$, Muhammad Marsudi ${ }^{1}$, Ice Trianiza ${ }^{1}$ \\ ${ }^{1}$ Teknik Industri, Fakultas Teknik, Universitas Islam Kalimantan Muhammad Arsyad Al-Banjari \\ Jl. Adhyaksa, Jl. Kayu Tangi 1 Jalur 2 No.2, Sungai Miai, Kec. Banjarmasin Utara, Kota Banjarmasin, \\ Kalimantan Selatan 70123 \\ Email : cintiaamaliatpc@gmail.com
}

\begin{abstract}
Abstrak- Pada sebuah perusahaan seperti PDAM, sistem produksinya sangat bergantung pada pompa. Pompa dituntut agar selalu dapat bekerja secara maksimal, efektif, efisien dan jauh dari kerusakan. PDAM Bandarmasih menggunakan cara manual untuk evaluasi mesin tiap bulannya, yaitu dengan cara pengecekan jumlah debit air yang dihasilkan. Maka dari itu dilakukan evaluasi mesin atau mengukur efektivitas mesin pompa distribusi dengan metode OEE (Overall Equipment Effectiveness). Lalu dilakukan perhitungan Six Big Losses dan diagram sebab akibat (fishbone) guna menganalisa masalah yang terjadi pada mesin tersebut. Perhitungan menggunakan data kurun waktu satu tahun pada periode Bulan Juni 2020 Mei 2021. Mesin pompa distribusi A availability pada kisaran 99,77\% sampai 99,92\%, performance dikisaran 94,06\% sampai $\mathbf{9 9 , 2 7 \%}$ dan quality pada kisaran $\mathbf{9 8 , 3 3} \%$ sampai $\mathbf{1 0 0} \%$ dan OEE antara $93,88 \%$ sampai $98,50 \%$. Mesin pompa distribusi B, availability diperoleh dikisaran $99,77 \%$ sampai $100 \%$, performance pada kisaran $93,07 \%$ sampai $99,58 \%$, quality pada kisaran angka $85,48 \%$ sampai dengan $100 \%$ dan OEE pada kisaran 84,98\% sampai $98,82 \%$. Mesin pompa $C$, availability pada kisaran $99,65 \%$ sampai $100 \%$, performance dikisaran $\mathbf{9 2 , 8 2 \%}$ sampai $98,98 \%$, quality pada kisaran $85,48 \%$ sampai $100 \%$ dan OEE pada kisaran $84,96 \%$ sampai $98,82 \%$. Mesin pompa distribusi $\mathrm{D}$, availability pada kisaran $99,49 \%$ sampai $100 \%$, performance pada kisaran $93,08 \%$ sampai $99 \%$, quality berada pada kisaran $85,48 \%$ sampai $100 \%$ dan OEE pada kisaran $84,98 \%$ sampai $98,82 \%$. Mesin pompa distribusi $E$ availability pada kisaran $84,34 \%$ sampai $99,85 \%$, performance pada kisaran $80,11 \%$ sampai $99,97 \%$, quality dikisaran $89,52 \%$ sampai $100 \%$, dan OEE pada kisaran $79,91 \%$ sampai $83,65 \%$. Mesin pompa distribusi $\mathrm{F}$, availability pada kisaran $99,76 \%$ sampai 99,89\%, performance dikisaran $93,04 \%$ sampai $99,63 \%$, quality pada kisaran $85,48 \%$ sampai $100 \%$ dan OEE pada kisaran $84,99 \%$ sampai $98,84 \%$. Dari hasil perhitungan yang diperoleh pada masing-masing mesin pompa dapat disimpulkan bahwa dari enam mesin pompa distribusi yang beroperasi, empat diantaranya sudah efektif dan dua mesin belum efektif.
\end{abstract}

Kata Kunci : OEE, Six Big Losses, diagram sebab akibat

\section{PENDAHULUAN}

$\mathrm{M}$ enggunakan cara manual untuk evaluasi mesin pompa di IPA II Pramuka, maka perlu dilakukan evaluasi menggunakan metode OEE yang berdasar pada tiga penilaian yaitu availability, performance, dan quality. Agar dapat diketahui kinerja pada masing-masing mesin pompa khususnya mesin pompa distribusi, apakah sudah memenuhi nilai ideal. Sehingga dapat ditentukan keefektivitasan dari mesin pompa distribusi. Lalu Tujuan dilakukannya penelitian ini adalah untuk mengidentifikasi nilai availability, performance dan quality dan mengidentifikasi efektivitas dari kinerja mesin pompa pada mesin pompa distribusi di IPA II Pramuka.

\section{OEE (Overall Equipment Effectiveness)}

Merupakan metode pengukuran dasar untuk mengukur kinerja. Overall equipment effectiveness adalah tingkat keefektifan fasilitas secara menyeluruh yang diperoleh dengan memperhitungkan availability rate, performance rate, dan rate of quality. Pengukuran OEE ini didasarkan pada pengukuran tiga rasio utama, yaitu: availability rate, performance rate, dan quality rate [2].

$$
\text { OEE = Availability } \mathrm{x} \text { Performance } \mathrm{x} \text { Quality }
$$

\section{Availability Rate}

Merupakan ketersediaan suatu mesin/peralatan. Perbandingan antara waktu operasi (operation time) terhadap waktu persiapan (loading time) dari suatu mesin atau peralatan. Untuk menghitung availability dibutuhkan nilai dari :
a. Operation time
b. Downtime
c. Loading time

$$
\text { Availability }=\frac{\text { Loading time-downtime }}{\text { loading time }} \times 100 \% \text { (2) }
$$

3. Performance Rate

adalah tolak ukur dari efisiensi suatu kinerja mesin dalam menjalankan proses produksi [4]. Terdapat tiga faktor yang dibutuhkan untuk menghitung performance rate yaitu :

a. Ideal Cycle Time

b. Processed Amount

c. Operation Time

$$
\text { Performance }=\frac{\text { processed amount } X \text { ideal cycle time }}{\text { operation time }} \times 100 \%
$$

4. Quality Rate

Adalah perbandingan jumlah produk yang baik terhadap jumlah produk yang diproses. Nilai quality dapat dihitung berdasarkan dua faktor yaitu :

a. Processed amount

b. Deffect amount

$$
\text { Quality }=\frac{\text { processed amount }- \text { deffect amount }}{\text { processed amount }} \times 100 \%
$$


Tabel 1. Nilai Ideal

\begin{tabular}{|c|c|}
\hline Deskripsi & Nilai \\
\hline Availability & $>90 \%$ \\
Performance & $>95 \%$ \\
Quality & $>99 \%$ \\
OEE & $>85 \%$ \\
\hline
\end{tabular}

Sumber : (Seichi Nakajima, 1989)

\section{Six Big Losses}

a. Downtime Losses

- Breakdown losses, kerusakan mesin/peralatan yang tidak diinginkan dan menimbulkan penurunan output, waktu yang sia-sia atau reject dari barang produksi.

$$
\frac{\text { breakdown time }}{\text { loading time }} \times 100 \%
$$

- Set up \& Adjustment, kerugian yang disebabkan oleh kegiatan set up dan penyesuaian untuk mengganti suatu jenis produk untuk proses produksi berikutnya.

$$
\frac{\text { set up \& adjustment }}{\text { loading time }} \times 100 \%
$$

b. Speed Losses

- Idling \& minor stoppages losses, kerugian berhentinya mesin sejenak, atau kemacetan mesin.

$$
\frac{\text { non productive time }}{\text { loading time }} \times 100 \%
$$

- Reduced speed loss, kerugian karena kecepatan aktual berada di bawah kecepatan optimal dari mesin.

$\frac{\text { actual processing time-ideal processing time }}{\text { loading time }} \times 100 \%$

c. Quality Losses

- Process deffect losses, kerugian yang timbul karena adanya produk yang cacat.

ideal cycle time $X$ total process deffect loading time $X 100 \%$

- Reduced yield losses, kerugian waktu dan material yang timbul selama proses produksi karena keadaan operasi yang tidak stabil dan penanganan tidak tepat. $\frac{\text { ideal cycle time } X \text { reduce yield }}{\text { loading time }} \times 100 \%$

(10)

\section{METODE PENELITIAN}

\section{Tempat Penelitian}

Tempat yang digunakan untuk melakukan penelitian ini berada di IPA II Pramuka PDAM Bandarmasih.

\section{Pengolahan Data}

a. Machine Working Times, merupakan tersedianya waktu pada penggunaan mesin dalam satu hari dan dapat ditambah dengan waktu lembur apabila waktu tersebut tersedia di perusahaan.

b. Loading Time, adalah hasil dari waktu yang tersedia (Machine Working Times) dikurang dengan Planned Downtime.

c. Downtime, merupakan waktu yang terserap tanpa menghasilkan output karena kerusakan mesin. Waktu Set up \& Adjustment ditambah dengan Breakdown Time.

d. Planned Downtime, yaitu waktu yang digunakan pada saat pelaksanaan Preventive Maintenance atau aktivitas Maintenance lainnya yang sudah dijadwalkan.

e. Breakdown Time, merupakan waktu berhentinya suatu mesin dalam beroperasi seperti terjadi kerusakan pada bagian tertentu ataupun pergantian dies.

f. Set up \& Adjustment, adalah kegiatan seperti setting mesin atau briefiing sebelum dimulainya proses produksi.

g. Processed Amount, merupakan jumlah produk yang diproses atau diproduksi.

h. Ideal Cycle Time, adalah waktu standar atau waktu proses yang diharapkan dapat dicapai tanpa ada hambatan selama proses produksi

i. Total Deffect, yaitu total produk yang ditolak karena cacat atau tidak memenuhi standar 


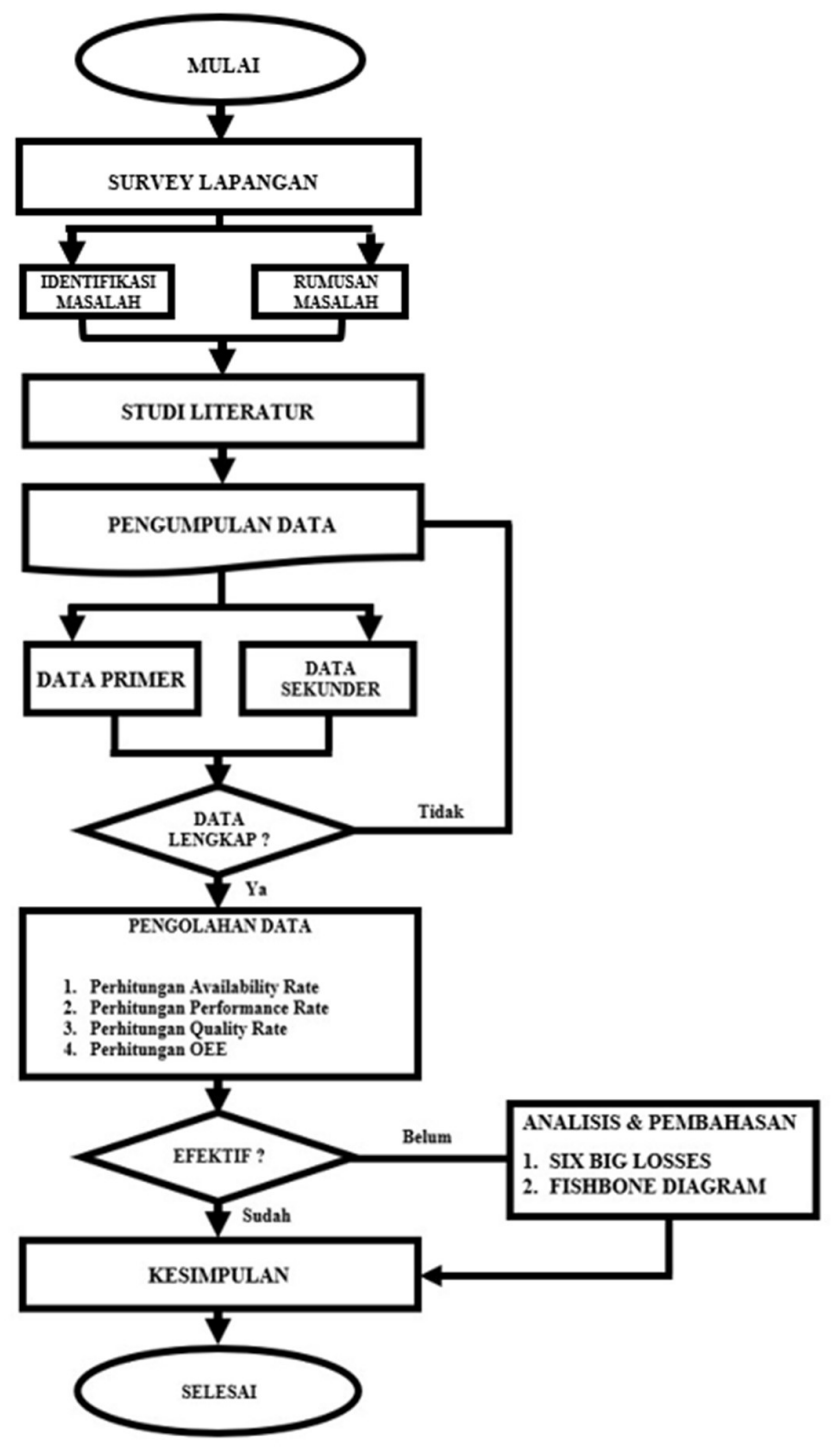

Gambar 1. Bagan Alir

\section{HASIL DAN PEMBAHASAN}

\section{Pengumpulan dan Pengolahan Data}

Pada penggunaan mesin pompa distribusi di IPA II Pramuka, tidak semua mesin pompa dioperasikan. Hanya tiga sampai empat mesin saja yang digunakan untuk mendistribusikan air setiap harinya. Dua diantaranya harus beroperasi full selama 24 jam dan mesin lainnya beroperasi kurang dari 24 jam/harinya.

Tabel 2 Spesifikasi Mesin Pompa

\begin{tabular}{|c|c|c|c|}
\hline Mesin & Merk & Type & $\begin{array}{c}\text { Tahun } \\
\text { Terpasang }\end{array}$ \\
\hline A & \multirow{6}{*}{$\begin{array}{l}\text { Torishima } \\
\text { Pump }\end{array}$} & \multirow{6}{*}{$\begin{array}{c}\text { CDM } \\
350 \mathrm{X} \\
250 \mathrm{FN}\end{array}$} & 2014 \\
\hline B & & & 2015 \\
\hline $\mathrm{C}$ & & & 2015 \\
\hline $\mathrm{D}$ & & & 2014 \\
\hline $\mathrm{E}$ & & & 2015 \\
\hline $\mathrm{F}$ & & & 2015 \\
\hline
\end{tabular}

Sumber : IPA II Pramuka 
1. Perhitungan Availability, Performance, Quality dan OEE

Tabel 3. Hasil perhitungan Availability, Performance, Quality dan OEE

\begin{tabular}{|c|c|c|c|c|}
\hline \multicolumn{5}{|c|}{ Mesin A } \\
\hline Bulan & Availability & Performance & Quality & OEE \\
\hline Jun & $99,82 \%$ & $94,37 \%$ & $100 \%$ & $94,20 \%$ \\
\hline Jul & $99,81 \%$ & $94,06 \%$ & $100 \%$ & $93,88 \%$ \\
\hline Agt & $99,90 \%$ & $98,59 \%$ & $100 \%$ & $98,50 \%$ \\
\hline Sep & $99,78 \%$ & $94,50 \%$ & $100 \%$ & $94,29 \%$ \\
\hline Okt & $99,92 \%$ & $96,31 \%$ & $100 \%$ & $96,24 \%$ \\
\hline Nov & $99,77 \%$ & $98,54 \%$ & $100 \%$ & $98,32 \%$ \\
\hline Des & $99,80 \%$ & $99,27 \%$ & $98,33 \%$ & $97,42 \%$ \\
\hline Jan & - & - & - & - \\
\hline Feb & - & - & - & - \\
\hline Mar & - & - & - & - \\
\hline Apr & - & - & - & - \\
\hline Mei & - & - & - & - \\
\hline \multicolumn{4}{|r|}{ Rata-rata } & $56,07 \%$ \\
\hline \multicolumn{5}{|c|}{ Mesin B } \\
\hline Jun & $99,92 \%$ & $93,24 \%$ & $100 \%$ & $93,16 \%$ \\
\hline Jul & $99,80 \%$ & $93,07 \%$ & $100 \%$ & $92,88 \%$ \\
\hline Agt & $99,82 \%$ & $97,66 \%$ & $100 \%$ & $97,48 \%$ \\
\hline Sep & $99,77 \%$ & $93,51 \%$ & $100 \%$ & $93,29 \%$ \\
\hline Okt & $99,77 \%$ & $95,48 \%$ & $100 \%$ & $95,26 \%$ \\
\hline Nov & $99,88 \%$ & $97,35 \%$ & $100 \%$ & $97,23 \%$ \\
\hline Des & $99,80 \%$ & $98,21 \%$ & $98,33 \%$ & $96,38 \%$ \\
\hline Jan & $100 \%$ & $97,97 \%$ & $89,52 \%$ & $87,70 \%$ \\
\hline Feb & $99,83 \%$ & $99,58 \%$ & $85,48 \%$ & $84,98 \%$ \\
\hline Mar & $99,85 \%$ & $96,44 \%$ & $88,39 \%$ & $85,11 \%$ \\
\hline Apr & $99,86 \%$ & $98,53 \%$ & $96,77 \%$ & $95,22 \%$ \\
\hline Mei & $99,80 \%$ & $99,02 \%$ & $100 \%$ & $98,82 \%$ \\
\hline Jun & $99,92 \%$ & $93,24 \%$ & $100 \%$ & $93,16 \%$ \\
\hline \multicolumn{4}{|r|}{ Rata-rata } & $93,13 \%$ \\
\hline \multicolumn{5}{|c|}{ Mesin C } \\
\hline Jun & $99,79 \%$ & $93,39 \%$ & $100 \%$ & $93,20 \%$ \\
\hline Jul & $100,00 \%$ & $92,82 \%$ & $100 \%$ & $92,82 \%$ \\
\hline Agt & $99,65 \%$ & $97,87 \%$ & $100 \%$ & $97,53 \%$ \\
\hline Sep & $99,87 \%$ & $93,39 \%$ & $100 \%$ & $93,26 \%$ \\
\hline Okt & $99,86 \%$ & $95,37 \%$ & $100 \%$ & $95,23 \%$ \\
\hline Nov & $99,87 \%$ & $97,37 \%$ & $100 \%$ & $97,24 \%$ \\
\hline Des & $99,83 \%$ & $98,18 \%$ & $98,33 \%$ & $96,37 \%$ \\
\hline Jan & $99,92 \%$ & $98,07 \%$ & $89,52 \%$ & $87,72 \%$ \\
\hline Feb & $99,90 \%$ & $99,50 \%$ & $85,48 \%$ & $84,96 \%$ \\
\hline Mar & - & $0 \%$ & $0 \%$ & - \\
\hline Apr & $99,88 \%$ & $98,51 \%$ & $96,77 \%$ & $95,21 \%$ \\
\hline Mei & $99,83 \%$ & $98,98 \%$ & $100 \%$ & $98,82 \%$ \\
\hline \multicolumn{4}{|r|}{ Rata-rata } & $86,03 \%$ \\
\hline \multicolumn{5}{|c|}{ Mesin D } \\
\hline Jun & $99,69 \%$ & $93,53 \%$ & $100 \%$ & $93,23 \%$ \\
\hline Jul & $99,79 \%$ & $93,08 \%$ & $100 \%$ & $92,89 \%$ \\
\hline Agt & $99,49 \%$ & $98,08 \%$ & $100 \%$ & $97,58 \%$ \\
\hline Sep & $99,81 \%$ & $93,46 \%$ & $100 \%$ & $93,28 \%$ \\
\hline
\end{tabular}




\begin{tabular}{|c|c|c|c|c|}
\hline Okt & $99,80 \%$ & $95,44 \%$ & $100 \%$ & $95,25 \%$ \\
\hline Nov & $99,84 \%$ & $97,41 \%$ & $100 \%$ & $97,25 \%$ \\
\hline Des & $99,82 \%$ & $98,18 \%$ & $98,33 \%$ & $96,37 \%$ \\
\hline Jan & $100 \%$ & $97,97 \%$ & $89,52 \%$ & $87,70 \%$ \\
\hline Feb & $99,84 \%$ & $99,57 \%$ & $85,48 \%$ & $84,98 \%$ \\
\hline Mar & $99,85 \%$ & $96,44 \%$ & $88,39 \%$ & $85,12 \%$ \\
\hline Apr & $99,76 \%$ & $98,67 \%$ & $96,77 \%$ & $95,25 \%$ \\
\hline Mei & $99,82 \%$ & $99,00 \%$ & $100 \%$ & $98,82 \%$ \\
\hline \multicolumn{4}{|r|}{ Rata-rata } & $93,14 \%$ \\
\hline \multicolumn{5}{|c|}{ Mesin E } \\
\hline Jun & $99,83 \%$ & $80,31 \%$ & $100 \%$ & $80,16 \%$ \\
\hline Jul & $99,75 \%$ & $80,11 \%$ & $100 \%$ & $79,91 \%$ \\
\hline Agt & $99,83 \%$ & $83,99 \%$ & $100 \%$ & $83,85 \%$ \\
\hline Sep & $99,80 \%$ & $80,40 \%$ & $100 \%$ & $80,24 \%$ \\
\hline Okt & $99,85 \%$ & $82,05 \%$ & $100 \%$ & $81,92 \%$ \\
\hline Nov & $99,85 \%$ & $83,78 \%$ & $100 \%$ & $83,65 \%$ \\
\hline Des & - & $0 \%$ & $0 \%$ & - \\
\hline Jan & $84,34 \%$ & $99,97 \%$ & $89,52 \%$ & $75,47 \%$ \\
\hline Feb & - & $0 \%$ & $0 \%$ & - \\
\hline Mar & - & $0 \%$ & $0 \%$ & - \\
\hline Apr & - & $0 \%$ & $0 \%$ & - \\
\hline Mei & - & $0 \%$ & $0 \%$ & - \\
\hline \multicolumn{4}{|r|}{ Rata-rata } & $47,10 \%$ \\
\hline \multicolumn{5}{|c|}{ Mesin F } \\
\hline Jun & $99,81 \%$ & $93,37 \%$ & $100 \%$ & $93,20 \%$ \\
\hline Jul & $99,83 \%$ & $93,04 \%$ & $100 \%$ & $92,88 \%$ \\
\hline $\mathrm{Agt}$ & $99,81 \%$ & $97,66 \%$ & $100 \%$ & $97,48 \%$ \\
\hline Sep & $99,82 \%$ & $93,45 \%$ & $100 \%$ & $93,28 \%$ \\
\hline Okt & $99,82 \%$ & $95,42 \%$ & $100 \%$ & $95,24 \%$ \\
\hline Nov & $99,76 \%$ & $97,51 \%$ & $100 \%$ & $97,27 \%$ \\
\hline Des & $99,83 \%$ & $98,17 \%$ & $98,33 \%$ & $96,37 \%$ \\
\hline Jan & $99,89 \%$ & $98,12 \%$ & $89,52 \%$ & $87,74 \%$ \\
\hline Feb & $99,80 \%$ & $99,63 \%$ & $85,48 \%$ & $84,99 \%$ \\
\hline Mar & $99,77 \%$ & $96,54 \%$ & $88,39 \%$ & $85,14 \%$ \\
\hline Apr & $99,81 \%$ & $98,60 \%$ & $96,77 \%$ & $95,24 \%$ \\
\hline Mei & $99,76 \%$ & $99,07 \%$ & $100 \%$ & $98,84 \%$ \\
\hline \multicolumn{4}{|r|}{ Rata-rata } & $93,14 \%$ \\
\hline
\end{tabular}

Setelah diperoleh hasil dari perhitungan availability, performance, quality dan OEE. Selanjutnya dilakukan perhitungan rata-rata OEE dalam kurun waktu satu tahun, sehingga dapat diketahui mesin pompa distribusi apa saja yang sudah memenuhi nilai ideal. Hasil pada tampilan grafik, diketahui nilai paling rendah ada pada mesin $\mathrm{E}$ dan $\mathrm{A}$, maka disimpulkan bahwa mesin tersebut belum efektif karena belum mencapai nilai idealnya. Lalu mesin yang sudah efektif adalah mesin pompa distribusi $\mathrm{C}$, karena nilai yang diperoleh sudah sesuai nilai idealnya. 


\section{OEE/Tahun}

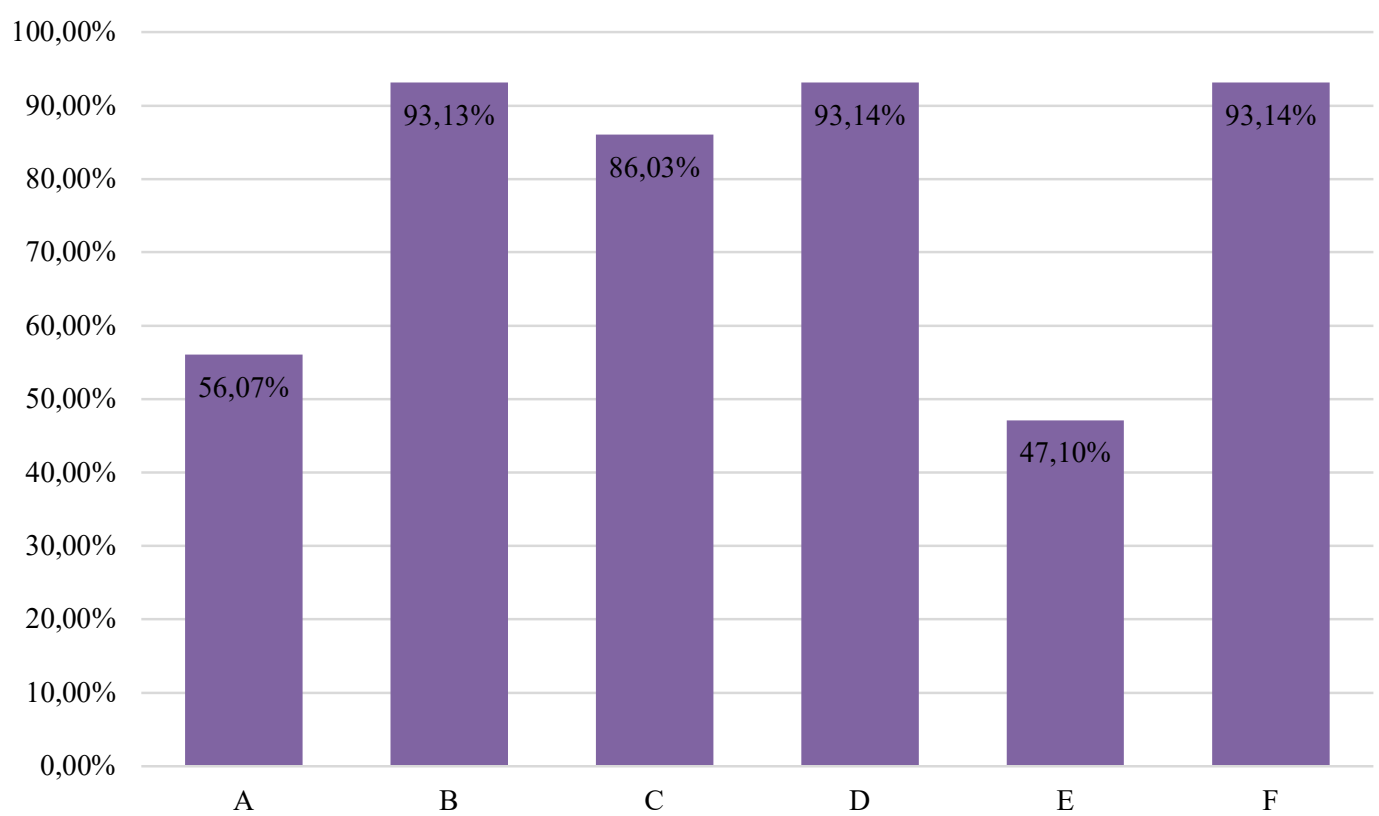

Gambar 2. Nilai rata-rata OEE per tahun

Dan mesin paling efektif adalah mesin pompa distribusi $\mathrm{B}$, D, dan F, karena perolehan nilai rata-rata OEE selama satu tahun melampaui nilai idealnya serta mesin tersebut juga dapat beroperasi penuh dalam kurun waktu satu tahun dan tidak ada terjadi kerusakan pada mesin pompa distribusi.

Tabel 4 Peringkat efektivitas mesin pompa distribusi

\begin{tabular}{|c|c|c|c|}
\hline Peringkat & Mesin Pompa & $\begin{array}{c}\text { Nilai } \\
\text { Rata-rata }\end{array}$ & Keterangan \\
\hline 1 & D dan F & $93,14 \%$ & Efektif \\
\hline 2 & B & $93,13 \%$ & Efektif \\
\hline 3 & C & $86,03 \%$ & Efektif \\
\hline 4 & A & $56,07 \%$ & Belum Efektif \\
\hline 5 & E & $47,10 \%$ & Belum Efektif \\
\hline
\end{tabular}

\section{Perhitungan Six big Losses}

Karena mesin A dan E belum efektif, maka dilakukan analisa dengan six big losses. Perhitungan mesin A dan E berupa perhitungan downtime losses, speed losses, dan quality losses. Berikut hasil perhitungannya,

a. Downtime Losses

- Breakdown Losses

Tabel 5 Hasil perhitungan breakdown losses

\begin{tabular}{|c|c|c|c|}
\hline Bulan & Loading Time & Breakdown & Hasil \\
\hline \multicolumn{4}{|c|}{ Mesin A } \\
\hline Jun & 542,67 & 0 & $0 \%$ \\
\hline Jul & 520,67 & 0 & $0 \%$ \\
\hline Agt & 516,83 & 0 & $0 \%$ \\
\hline Sep & 336,75 & 0 & $0 \%$ \\
\hline Okt & 312,92 & 0 & $0 \%$ \\
\hline Nov & 327,75 & 0 & $0 \%$ \\
\hline Des & 247,83 & 0 & $0 \%$ \\
\hline
\end{tabular}




\begin{tabular}{|c|c|c|c|}
\hline Jan & - & 744 & - \\
\hline Feb & - & 744 & - \\
\hline Mar & - & 672 & - \\
\hline Apr & - & 744 & - \\
\hline Mei & - & 720 & - \\
\hline \multicolumn{4}{|c|}{ Mesin E } \\
\hline Jun & 142,92 & 0 & $0 \%$ \\
\hline Jul & 399,67 & 0 & $0 \%$ \\
\hline Agt & 449,75 & 0 & $0 \%$ \\
\hline Sep & 506,67 & 0 & $0 \%$ \\
\hline Okt & 491,75 & 0 & $0 \%$ \\
\hline Nov & 491,75 & 0 & $0 \%$ \\
\hline Des & - & 0 & - \\
\hline Jan & 462,83 & 72 & $16 \%$ \\
\hline Feb & - & 744 & - \\
\hline Mar & - & 672 & - \\
\hline Apr & - & 720 & - \\
\hline Mei & - & 0 & - \\
\hline
\end{tabular}

- Set-up \& Adjustment

Tabel 6 Hasil perhitungan set-up \& adjustment

\begin{tabular}{|c|c|c|c|}
\hline Bulan & Loading Time & Set-up \& Adj & Hasil \\
\hline \multicolumn{4}{|c|}{ Mesin A } \\
\hline Jun & 542,67 & 0,25 & $0,05 \%$ \\
\hline Jul & 520,67 & 0,25 & $0,05 \%$ \\
\hline Agt & 516,83 & 0,25 & $0,05 \%$ \\
\hline Sep & 336,75 & 0,25 & $0,07 \%$ \\
\hline Okt & 312,92 & 0,25 & $0,08 \%$ \\
\hline Nov & 327,75 & 0,25 & $0,08 \%$ \\
\hline Des & 247,83 & 0,25 & $0,10 \%$ \\
\hline Jan & - & - & - \\
\hline Feb & - & - & - \\
\hline Mar & - & - & - \\
\hline Apr & - & - & - \\
\hline Mei & - & - & - \\
\hline \multicolumn{5}{|c|}{ Mesin E } & 0,25 & $0,17 \%$ \\
\hline Jun & 142,92 & 1 & $0,25 \%$ \\
\hline Jul & 399,67 & 0,75 & $0,17 \%$ \\
\hline Agt & 449,75 & 1 & $0,20 \%$ \\
\hline Sep & 506,67 & 0,75 & $0,15 \%$ \\
\hline Okt & 491,75 & 0,75 & $0,15 \%$ \\
\hline Nov & 491,75 & 0 & - \\
\hline Des & - & 0,5 & $0,11 \%$ \\
\hline Jan & 462,83 & 0 & - \\
\hline Feb & - & 0 & - \\
\hline Mar & - & 0 & - \\
\hline Apr & - & & - \\
\hline Mei & - & & \\
\hline
\end{tabular}


b. Speed Losses

- Idling \& Minor Stoppages Losses

Tabel 7 Hasil perhitungan idling \& minor stoppages losses

\begin{tabular}{|c|c|c|c|}
\hline Bulan & $\begin{array}{c}\text { Non Productive } \\
\text { Time }\end{array}$ & Loading Time & Hasil \\
\hline \multicolumn{4}{|c|}{ Mesin A } \\
\hline Jun & 129 & 543 & $24 \%$ \\
\hline Jul & 79 & 521 & $15 \%$ \\
\hline Agt & 35 & 516,83 & $7 \%$ \\
\hline Sep & 71 & 336,75 & $21 \%$ \\
\hline Okt & 71 & 312,92 & $23 \%$ \\
\hline Nov & 80 & 327,75 & $24 \%$ \\
\hline Des & 40 & 247,83 & $16 \%$ \\
\hline Jan & - & - & - \\
\hline Feb & - & - & - \\
\hline Mar & - & - & - \\
\hline Apr & - & - & - \\
\hline Mei & - & - & - \\
\hline \multicolumn{4}{|c|}{ Mesin E } \\
\hline Jun & 97 & 142,92 & $68 \%$ \\
\hline Jul & 200 & 399,67 & $50 \%$ \\
\hline Agt & 174 & 449,75 & $39 \%$ \\
\hline Sep & 117 & 506,67 & $23 \%$ \\
\hline Okt & 108 & 491,75 & $22 \%$ \\
\hline Nov & 108 & 491,75 & $22 \%$ \\
\hline Des & 0 & - & - \\
\hline Jan & 41 & 462,83 & $9 \%$ \\
\hline Feb & 0 & - & - \\
\hline Mar & 0 & - & - \\
\hline Apr & 0 & - & - \\
\hline Mei & 0 & - \\
\hline
\end{tabular}

- Reduced Speed Losses

Tabel 8 Hasil perhitungan reduced speed losses

\begin{tabular}{|c|c|c|c|c|c|}
\hline Bulan & $\begin{array}{c}\text { Waktu } \\
\text { produksi } \\
\text { aktual }\end{array}$ & $\begin{array}{c}\text { Ideal cycle } \\
\text { time }\end{array}$ & $\begin{array}{c}\text { Hasil } \\
\text { produksi }\end{array}$ & $\begin{array}{l}\text { Loading } \\
\text { time }\end{array}$ & Hasil \\
\hline \multicolumn{6}{|c|}{ Mesin A } \\
\hline Jun & 672 & \multirow{8}{*}{0,00095} & 543.802 & 542,67 & $29 \%$ \\
\hline Jul & 600 & & 520.009 & 520,67 & $20 \%$ \\
\hline Agt & 552 & & 541.557 & 516,83 & $7 \%$ \\
\hline Sep & 408 & & 337.803 & 336,75 & $26 \%$ \\
\hline Okt & 384 & & 320.360 & 312,92 & $25 \%$ \\
\hline Nov & 408 & & 342.800 & 327,75 & $25 \%$ \\
\hline Des & 288 & & 261.197 & 247,83 & $16 \%$ \\
\hline Jan & 0 & & 0 & - & - \\
\hline
\end{tabular}




\begin{tabular}{|c|c|c|c|c|c|}
\hline Feb & 0 & & 0 & - & - \\
\hline Mar & 0 & & 0 & - & - \\
\hline Apr & 0 & & 0 & - & - \\
\hline Mei & 0 & & 0 & - & - \\
\hline \multicolumn{6}{|c|}{ Mesin E } \\
\hline Jun & 240 & \multirow{12}{*}{0,0008} & 143.211 & 142,92 & $88 \%$ \\
\hline Jul & 600 & & 399.239 & 399,67 & $70 \%$ \\
\hline Agt & 624 & & 471.375 & 449,75 & $55 \%$ \\
\hline Sep & 624 & & 508.208 & 506,67 & $43 \%$ \\
\hline Okt & 600 & & 503.568 & 491,75 & $40 \%$ \\
\hline Nov & 600 & & 514.200 & 491,75 & $38 \%$ \\
\hline Des & 0 & & 0 & - & - \\
\hline Jan & 504 & & 487.761 & 462,83 & $25 \%$ \\
\hline Feb & 0 & & 0 & - & - \\
\hline Mar & 0 & & 0 & - & - \\
\hline Apr & 0 & & 0 & - & - \\
\hline Mei & 0 & & 0 & - & - \\
\hline
\end{tabular}

c. Quality Losses

- Rework Losses

Tabel 9 Hasil perhitungan rework losses

\begin{tabular}{|c|c|c|c|c|}
\hline Bulan & $\begin{array}{c}\text { Ideal Cycle } \\
\text { Time }\end{array}$ & Rework & Loading Time & Hasil \\
\hline \multicolumn{5}{|c|}{ Mesin A } \\
\hline Jun & \multirow{12}{*}{0,00095} & 0 & 543 & $0 \%$ \\
\hline Jul & & 0 & 521 & $0 \%$ \\
\hline Agt & & 0 & 516,83 & $0 \%$ \\
\hline Sep & & 0 & 336,75 & $0 \%$ \\
\hline Okt & & 0 & 312,92 & $0 \%$ \\
\hline Nov & & 0 & 327,75 & $0 \%$ \\
\hline Des & & 0 & 247,83 & - \\
\hline Jan & & 0 & - & - \\
\hline Feb & & 0 & - & - \\
\hline Mar & & 0 & - & - \\
\hline Apr & & 0 & - & - \\
\hline Mei & & 0 & - & - \\
\hline \multicolumn{5}{|c|}{ Mesin E } \\
\hline Jun & \multirow{12}{*}{0,0008} & 0 & 142,92 & $0 \%$ \\
\hline Jul & & 0 & 399,67 & $0 \%$ \\
\hline Agt & & 0 & 449,75 & $0 \%$ \\
\hline Sep & & 0 & 506,67 & $0 \%$ \\
\hline Okt & & 0 & 491,75 & $0 \%$ \\
\hline Nov & & 0 & 491,75 & $0 \%$ \\
\hline Des & & 0 & - & - \\
\hline Jan & & 0 & 462,83 & $0 \%$ \\
\hline Feb & & 0 & - & - \\
\hline Mar & & 0 & - & - \\
\hline Apr & & 0 & - & - \\
\hline Mei & & 0 & - & - \\
\hline
\end{tabular}


- Reduced Yield Losses

Tabel 10 Hasil perhitungan reduced yield losses

\begin{tabular}{|c|c|c|c|c|}
\hline Bulan & $\begin{array}{c}\text { Ideal Cycle } \\
\text { Time }\end{array}$ & Rework & Loading Time & Hasil \\
\hline \multicolumn{5}{|c|}{ Mesin A } \\
\hline Jun & \multirow{12}{*}{0,00095} & 0 & 543 & $0 \%$ \\
\hline Jul & & 0 & 521 & $0 \%$ \\
\hline Agt & & 0 & 516,83 & $0 \%$ \\
\hline Sep & & 0 & 336,75 & $0 \%$ \\
\hline Okt & & 0 & 312,92 & $0 \%$ \\
\hline Nov & & 0 & 327,75 & $0 \%$ \\
\hline Des & & 0 & 247,83 & - \\
\hline Jan & & 0 & - & - \\
\hline Feb & & 0 & - & - \\
\hline Mar & & 0 & - & - \\
\hline Apr & & 0 & - & - \\
\hline Mei & & 0 & - & - \\
\hline \multicolumn{5}{|c|}{ Mesin E } \\
\hline Jun & \multirow{12}{*}{0,0008} & 0 & 142,92 & $0 \%$ \\
\hline Jul & & 0 & 399,67 & $0 \%$ \\
\hline Agt & & 0 & 449,75 & $0 \%$ \\
\hline Sep & & 0 & 506,67 & $0 \%$ \\
\hline Okt & & 0 & 491,75 & $0 \%$ \\
\hline Nov & & 0 & 491,75 & $0 \%$ \\
\hline Des & & 0 & - & - \\
\hline Jan & & 0 & 462,83 & $0 \%$ \\
\hline Feb & & 0 & - & - \\
\hline Mar & & 0 & - & - \\
\hline Apr & & 0 & - & - \\
\hline Mei & & 0 & - & - \\
\hline
\end{tabular}

3. Diagram Sebab Akibat (Fishbone)

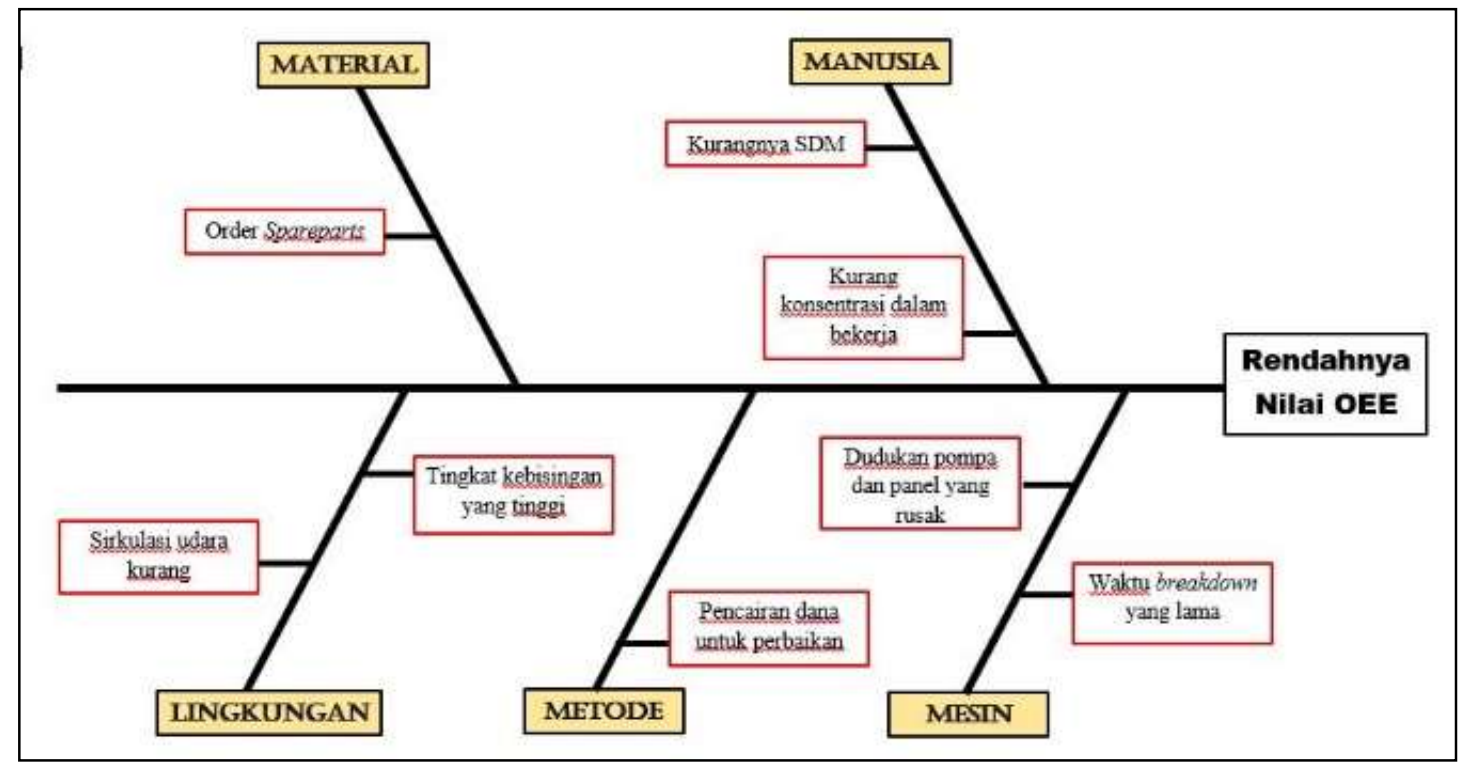

Gambar 3 Diagram sebab akibat 
Analisa dilakukan dengan melakukan wawancara terhadap supervisor pada divisi yang berkaitan yaitu Mekanika Elektrika dan Produksi. Diketahui bahwa ada 5 kategori penyebab rendahnya nilai OEE pada mesin pompa distribusi A dan E dengan penjelasan sebagai berikut:

a. Manusia, yaitu kurangnya sumber daya manusia menyebabkan tertundanya untuk melakukan perbaikan. Lalu kurangnya konsentrasi staff Mekanika Elektrika dalam bekerja karena terbagi-baginya pekerjaan. Kurangnya sumber daya manusia menyebabkan staff harus menyelesaikan pekerjaan rutinitas terlebih dahulu, baru bisa melakukan pekerjaan yang lain.

b. Mesin, faktor yang mempengaruhi yaitu waktu breakdown yang lama sehingga mengakibatkan tingginya waktu non produktif mesin. Rusaknya panel pada mesin A dan dudukan pompa pada mesin E rusak.

c. Metode, faktor yang mempengaruhi yaitu pencairan dana untuk melakukan perbaikan. Karena membutuhkan dana dalam melakukan perbaikan, melakukan pengajuan dana dan membutuhkan waktu yang lama untuk pencairan dana tersebut.

d. Material, pada kategori ini faktor yang mempengaruhi adalah pemesanan spareparts. Lamanya waktu spareparts datang karena pemesanan menyebabkan lamanya penanganan pada mesin.

e. Lingkungan, kurangnya sirkulasi udara menyebabkan pengap didalam ruangan mesin sehingga membuat staff kurang nyaman dalam melakukan pekerjaan. Lalu tingkat kebisingan yang tinggi membuat staff kurang berkonsentrasi dalam melakukan pekerjaannya.

\section{Usulan Pemecahan Masalah}

Faktor yang paling berpengaruh pada rendahnya nilai OEE yang diperoleh yaitu pada permasalahan pencairan dana untuk perbaikan mesin yang rusak. Karena membutuhkan waktu yang tidak sebentar dalam pencairan dana perbaikan, mengakibatkan mesin lama untuk diperbaiki, maka usulan pemecahan masalah yang dapat diberikan yaitu menyiapkan dana tak terduga jika dikemudian hari terjadi kerusakan berat, sehingga hanya membutuhkan biaya tambahan saja dan tidak menunggu waktu yang lama untuk pencairan dana dari direksi.

\section{KESIMPULAN DAN SARAN}

a. Mesin pompa distribusi A availability pada kisaran 99,77\% sampai 99,92\%, performance dikisaran 94,06\% sampai 99,27\% dan quality pada kisaran 98,33\% sampai $100 \%$ dan OEE antara 93,88\% sampai 98,50\%. Mesin pompa distribusi $\mathrm{B}$, availability diperoleh dikisaran $99,77 \%$ sampai $100 \%$, performance pada kisaran $93,07 \%$ sampai 99,58\%, quality pada kisaran angka $85,48 \%$ sampai dengan $100 \%$ dan OEE pada kisaran $84,98 \%$ sampai $98,82 \%$. Mesin pompa C, availability pada kisaran 99,65\% sampai $100 \%$, performance dikisaran $92,82 \%$ sampai $98,98 \%$, quality pada kisaran $85,48 \%$ sampai $100 \%$ dan OEE pada kisaran $84,96 \%$ sampai $98,82 \%$. Mesin pompa distribusi D, availability pada kisaran 99,49\% sampai 100\%, performance pada kisaran 93,08\% sampai 99\%, quality berada pada kisaran $85,48 \%$ sampai $100 \%$ dan OEE pada kisaran $84,98 \%$ sampai $98,82 \%$. Mesin pompa distribusi E availability pada kisaran $84,34 \%$ sampai $99,85 \%$, performance pada kisaran $80,11 \%$ sampai $99,97 \%$, quality dikisaran $89,52 \%$ sampai $100 \%$, dan OEE pada kisaran 79,91\% sampai $83,65 \%$. Mesin pompa distribusi F, availability pada kisaran 99,76\% sampai 99,89\%, performance dikisaran 93,04\% sampai 99,63\%, quality pada kisaran $85,48 \%$ sampai $100 \%$ dan OEE pada kisaran $84,99 \%$ sampai $98,84 \%$.

b. Dari hasil perhitungan yang diperoleh selama kurun waktu satu tahun, maka dapat disimpulkan bahwa dari enam mesin pompa distribusi yang beroperasi, 4 diantaranya yaitu mesin B, C, D dan F sudah efektif lalu 2 mesin belum efektif yaitu mesin A dan E.. Mesin A dan E dinyatakan belum efektif karena perolehan nilai ratarata OEE dalam kurun waktu satu tahun belum mencapai nilai idealnya.

\section{DAFTAR PUSTAKA}

[1] Amilia, K., Dahda, S. S., \& Ismiyah, E. (2017). Analisis Kinerja Fasilitas Produksi Dioctyle Phtalate dan Diisononyl Phthalate dengan Menggunakan Metode Overall Equipment Effectiveness. JUSTI (Jurnal Sistem dan Teknik Industri), 164-186.

[2] Ansori, N dan M. Imron Mustajib. (2013). Sistem Perawatan Terpadu (Integrated Maintenance System. Graha Ilmu. Yogyakarta

[3] Damos, C. R. (2018). Analisis Efektivitas Mesin Pulverizer pada PLTU Menggunakan Metode Overall Equipment Effectiveness (OEE). Skripsi.

[4] Darmawan, TD. Dan B. Suhardi. (2017). Analisis Overall Equipment Effectiveness 2017 dalam meminimalisasi Six Big Losses pada Area kiln di PT. Semen Indonesia (Persero) Tbk. Surakarta: Universitas Sebelas Maret.

[5] Jannah, R. M., Supriyadi, \& Nalhadi, A. (2017). Analisis Efektivitas pada Mesin Centrifugal dengan Menggunakan Metode Overall Equipment Effectiveness (OEE). Seminar Nasional Riset Terapan (SENASSET) 2017, 70-75.

[6] Mulyati, D., Sentia, P. D., Irhamni, \& A, Z. (2017). Analisis Perawatan Mesin Pendistribusian Air Bersih Menggunakan Metode Overall Equipment Effectiveness (OEE) Pada PDAM Unit Lambaro. Serambi Engineering, 176-181.

[7] Nakajima, Seichi. (1989). Introduction to Total Productive Maintenance. $1^{\text {st }}$ Edition. Productivity Press, Inc, Cambridge

[8] Putra, R. A. (2019). Analisis Kinerja Mesin Pompa Soda Ash dengan Perhitungan Overall Equipment Effectiveness dan Usulan Perbaikan dengan Total Productive Maintenance di IPA PDAM Tirtanadi Sunggal. Skripsi.

[9] Saipudin, S. (2019). Analisis Perhitungan Overall Equipment Effectiveness (OEE) Untuk Peningkatan Nilai Efektivitas Mesin Oven Line 7 pada PT. UPA. Skripsi.

[10] Setiawan, M. A. (2016). Manajemen Pemeliharaan Mesin Copymilling dengan Menerapkan Total Productive Maintenance (TPM) di Inter Metal Technology. Skripsi.

[11] Triwardani, D. H., Rahman, A., \& Tantrika, C. F. (2013). Analisis Overall Eqipment Effectiveness (OEE) Dalam Meminimalisi Six Big Losses Pada Mesin Produksi Dual Filters DD07 (Studi Kasus : PT. Filtrona Indonesia, Surabaya, Jawa Timur). 379-391.

[12] Triyanto. (2019). Perhitungan dan Analisis Nilai Overall Equipment Effectiveness (OEE) pada Mesin Punching di PT. UMEDA 